\title{
Disruption of the striated muscle glycogen-targeting subunit of protein phosphatase 1: influence of the genetic background
}

\author{
James Paterson, Ian R Kelsall and Patricia T W Cohen \\ Medical Research Council Protein Phosphorylation Unit, College of Life Sciences, Sir James Black Centre, University of Dundee, Dow Street, Dundee DD1 5EH, UK \\ (Correspondence should be addressed to P T W Cohen; Email: p.t.w.cohen@dundee.ac.uk)
}

\begin{abstract}
A prediabetic phenotype of glucose intolerance, insulin resistance and obesity was observed at $\sim 12$ months of age in mice homozygous for a null allele of the major skeletal muscle glycogen-targeting subunit $\mathrm{G}_{\mathrm{M}}$ of protein phosphatase 1 (PP1) and derived from a 129/Ola donor strain. In this study, backcrossing of these $\mathrm{G}_{\mathrm{M}}^{-1-}$ mice (termed obese $\mathrm{G}_{\mathrm{M}}^{-1-}$ mice) onto two different genetic backgrounds gave rise to lean, glucose-tolerant, insulin-sensitive $\mathrm{G}_{\mathrm{M}}^{-1-}$ mice (termed lean $\mathrm{G}_{\mathrm{M}}^{-1-}$ mice), indicating that at least one variant gene in the 129/Ola background, not present in the C57BL/6 or 129s2/sV background, is required for the development of the prediabetic phenotype of obese $\mathrm{G}_{\mathrm{M}}^{-1-}$ mice. Slightly elevated AMPactivated protein kinase $\alpha 2$ activity in the skeletal muscle of lean $\mathrm{C} 57 \mathrm{BL} / 6 \mathrm{G}_{\mathrm{M}}^{-1-}$ mice was also observed to a lesser extent in the obese $\mathrm{G}_{\mathrm{M}}^{-1-}$ mice. Normal or slightly raised in vivo glucose transport in lean C57BL/6 $\mathrm{G}_{\mathrm{M}}^{-1-}$ mice compared with decreased glucose transport in the obese $\mathrm{G}_{\mathrm{M}}^{--}$mice supports the tenet that adequate transport of glucose may be a key factor in preventing the development of the prediabetic phenotype. The $\mathrm{pH} 6 \cdot 8 / \mathrm{pH} 8.6$ activity ratio of phosphorylase kinase was increased in lean $\mathrm{C} 57 \mathrm{BL} / 6 \mathrm{G}_{\mathrm{M}}^{--}$mice compared with controls indicating that phosphorylase kinase is an in vivo substrate of $\mathrm{PP} 1-\mathrm{G}_{\mathrm{M}}$.
\end{abstract}

Journal of Molecular Endocrinology (2008) 40, 47-59

\section{Introduction}

One of the problems in understanding type 2 diabetes is that multiple genes as well as environmental factors contribute to this disorder. In addition, current evidence indicates heterogeneity in the underlying genetic defects (Hansen \& Pedersen 2005, O'Rahilly et al. 2005). A feature commonly observed in type 2 diabetes is that insulin-stimulated glycogen synthesis is decreased in skeletal muscle (Shulman 2000). In this tissue, insulin stimulates glycogen synthesis via the translocation of the glucose transporter (GLUT4) and activation of glycogen synthase (GS; DeFronzo 1997, Shepherd \& Kahn 1999). Phosphorylation of GS by GS kinase-3 (GSK3) at sites 3a, b and c (now known to be Ser640, Ser644 and Ser648) leads to its inactivation, while dephosphorylation of these sites and activation of GS are catalysed by glycogen-bound protein phosphatase 1 (PP1) that is predominantly bound to the glycogen-targeting subunit $\mathrm{G}_{\mathrm{M}} / \mathrm{R}_{\mathrm{GL}}$ (encoded by the gene PPP1R3A) in skeletal muscle (Cohen 1999). Glycogen breakdown is catalysed by phosphorylase kinase and phosphorylase and the latter had been shown to be dephosphorylated with inactivation by PP1$\mathrm{G}_{\mathrm{M}}$ in vivo (Toole \& Cohen 2007). Variations in PPP1R3A, the gene-encoding $\mathrm{G}_{\mathrm{M}}$, have been noted in human populations and associated with diabetes in some populations but not others. For example, a five bp deletion mutation leading to decreased stability of $\mathrm{G}_{\mathrm{M}}$ mRNA was associated with diabetes in the Pima Indian population (Xia et al. 1998). In addition, the same mutation was found at higher frequencies in males diagnosed early with type 2 diabetes in a Scottish population (Doney et al. 2003). Individuals with severe insulin resistance within one family were identified as the only family members who were doubly heterozygous with respect to frameshift/premature stop mutations in the PPP1R3A and peroxisome proliferator-activated receptor $\gamma$ genes (Savage et al. 2002).

In order to determine the physiological role of $G_{M}$, two murine models homozygous for a null allele of $\mathrm{G}_{\mathrm{M}}$ have been generated in C57/BL6 backgrounds using donor cells from different substrains, 129/SvJ (Suzuki et al. 2001) and 129/Ola (Delibegovic et al. 2003). In both models, glycogen levels in skeletal muscle of $\mathrm{G}_{\mathrm{M}}^{-1-}$ mice were $10 \%$ of the levels in control mice, but blood glucose levels were not significantly different from controls. The proportion of phosphorylase in the active form in skeletal muscle was elevated in both models. However, the proportion of GS in the active form in the insulin-stimulated $\mathrm{G}_{\mathrm{M}}^{-1-}$ mice of Delibegovic et al. (2003) was less than that in the unstimulated control mice, whereas the proportions of GS in the active form in the insulin-stimulated $\mathrm{G}_{\mathrm{M}}^{-/-}$and control mice of Suzuki et al.

DOI: 10.1677/JME-07-0120 Online version via http://www.endocrinology-journals.org 
(2001) were not significantly different. Nevertheless, the most striking difference between the two models was that the $\mathrm{G}_{\mathrm{M}}^{-/-}$mice of Suzuki et al. (2001) remained lean, glucose tolerant and insulin sensitive up to 12 months of age, whereas the $\mathrm{G}_{\mathrm{M}}^{-1-}$ mice of Delibegovic et al. (2003) were obese with large abdominal fat deposits, glucose intolerant and insulin resistant at 11-12 months of age, and glucose uptake into skeletal muscle in vivo was decreased. This prediabetic phenotype is consistent with the concept that when blood glucose cannot be taken up and converted via GS into glycogen in skeletal muscle, the glucose is redirected (probably via the liver) into fat deposits that increase gradually with age. Development of insulin resistance may arise as a consequence of the increased fatty acids in older $\mathrm{G}_{\mathrm{M}}^{-/-}$mice. In order to investigate the factors accounting for the phenotypic differences between the two $\mathrm{G}_{\mathrm{M}}^{-1-}$ mice models, we have examined the genetic background, environmental factors and biochemical parameters.

\section{Materials and methods}

\section{Generation of $\mathbf{G}_{\mathbf{M}}$-deficient $\left(\mathrm{G}_{\mathbf{M}}^{--}\right)$mice}

All animal procedures were approved by the University of Dundee Ethical Committee and were performed under a UK Home Office Project Licence. Mice heterozygous for a null allele of $\mathrm{G}_{\mathrm{M}}$ (Delibegovic et al. 2003) were backcrossed to either C57BL/ 6 or $129 \mathrm{~s} 2 / \mathrm{sV}$ for at least six generations, before heterozygotes were intercrossed to produce mice homozygous for the null allele $\left(\mathrm{G}_{\mathrm{M}}^{-1-}\right)$, heterozygous, and homozygous for the wild-type allele $\left(\mathrm{G}_{\mathrm{M}}^{+/+}\right)$, which were used in the analyses described herein. All mice were maintained in temperature- and humiditycontrolled conditions with a $12 \mathrm{~h}$ light: $12 \mathrm{~h}$ darkness cycle and were allowed access to food and water ad libitum unless otherwise stated. Animals were fed either standard chow (nitrogen-free extract (NFE) 62\%), a low-carbohydrate diet (NFE $51 \%$ ) or a diet containing $30 \%$ extra glucose (NFE 72\%) all from Special Diet Services (Witham, Essex, UK). NFE is a measure of 'usable' carbohydrate content of a diet. Mice were genotyped by Southern blotting of ear DNA digested with $X b a I$, as described previously (Delibegovic et al. 2003).

\section{Immunological techniques}

Unless indicated otherwise, $20 \mu \mathrm{g}$ protein lysates were subjected to SDS-PAGE (Novex, Invitrogen) and transferred to nitrocellulose membranes. The membranes were incubated with affinity purified antibody at $1 \mu \mathrm{g} / \mathrm{ml}$ or at dilutions recommended by the suppliers in $50 \mathrm{mM}$ Tris- $\mathrm{HCl}(\mathrm{pH} \mathrm{7} 5$ ), $0 \cdot 15 \mathrm{M} \mathrm{NaCl}, 0 \cdot 1 \%$ (v/v)
Tween-20 containing $5 \%(\mathrm{w} / \mathrm{v})$ skimmed milk for $16 \mathrm{~h}$ at $4{ }^{\circ} \mathrm{C}$. Detection was performed using horseradish peroxidase-conjugated secondary antibodies and enhanced chemiluminescence or fluorescently labelled secondary antibodies and analysis using a Li-Cor Odyssey infrared detection system following the manufacturer's guidelines (Li-Cor, Cambridge, UK). The band intensity was quantified using Li-Cor software.

Antibodies to $\mathrm{G}_{\mathrm{M}}, \mathrm{PP} 1 \alpha$ and $\mathrm{PP} 1 \beta$, have been described previously (Delibegovic et al. 2003). Antibodies to humanPP2A $\mathrm{C}_{\mathrm{C}} \alpha / \beta$ (289-FDPAPRRGEPHVTRRTPDY$307)$ and the PH domain of protein kinase B (PKB) were raised in sheep by Diagnostics Scotland (Penicuik, Midlothian, UK) and affinity purified by the Division of Signal Transduction Therapy, University of Dundee, co-ordinated by Dr Hilary McLauchlan and Dr James Hastie. Peptides were synthesised by Dr G Bloomberg (University of Bristol, UK). Antibodies to phosphorylase kinase purified from rabbit skeletal muscle (Cohen 1983) were similarly raised in sheep and the immunoglobulin G (IgG) was isolated using protein G-Sepharose. Antibodies to rat AMP-activated protein kinase (AMPK) $\alpha 1$ (344-CTSPPDSFLDDHHLTR-358), AMPK $\alpha 2$ (352-CMDDSAMHIPPGLKPH-366) and AMPK phospho-Thr172 were supplied by Prof. D G Hardie (University of Dundee). Antibodies against PKB (phospho-Thr308), PKB $\alpha / \operatorname{PKB} \beta$ (phospho-Ser473), GSK3 $\alpha /$ GSK $\beta$ (phospho-Ser 21/9), acetyl-CoA carboxylase (ACC) and ACC phospho-Ser212 were from Cell Technology (Hitchin, UK). Other antibodies employed were: anti-GSK3 $\alpha /$ GSK3 $\beta$ (Biosource, Nivelles, Belgium), anti-GLUT4 from clone $1 \mathrm{~F} 8$ ((James et al. 1988), Biogenesis, Poole, UK) and antiGLUT4 C-terminal 15 amino acids (Abcam, Cambridge, UK). For analysis of GLUT4, the antiGLUT4 C-terminal antibody (Abcam) was covalently coupled to protein G-Sepharose beads and incubated with skeletal muscle lysates overnight at $4{ }^{\circ} \mathrm{C}$. The $10000 \mathrm{~g}$ immunopellets were washed three times and examined by sodium dodecyl gel electrophoresis followed by immunoblotting with anti-GLUT4 antibodies. Immunoblot analysis of ACC was performed according to Sakamoto et al. (2005), except that lysates were prepared with the addition of $1 \mu \mathrm{M}$ microcystin.

\section{Glucose and insulin tolerance testing}

Blood glucose levels were assessed using the AccuChek Blood Glucose Monitoring System (Roche Diagnostics). Glucose tolerance tests were performed on mice after a 12-14 h overnight fast. Mice were injected intraperitoneally with $2 \mathrm{mg}$ D-glucose/g, and blood glucose levels were determined immediately before and at 15, 30, 60 and $120 \mathrm{~min}$ following injection. Insulin tolerance was assessed by measuring blood glucose levels before and 
$15,30,60$ and $120 \mathrm{~min}$ after mice had received an i.p. injection of $1 \mathrm{mU} / \mathrm{g}$ insulin (Human Actrapid, $100 \mathrm{iU} / \mathrm{ml}$; Novo Nordisk Pharmaceuticals Ltd, Crawley, UK) after a 6 -h fast. In vivo glucose transport was determined after i.p. injection of 2-deoxy-D-[1,2- $\left.{ }^{3} \mathrm{H}\right]$ glucose mixed with $20 \%$ dextrose $(2 \mathrm{~g} / \mathrm{kg}$ body weight; $10 \mu \mathrm{Ci} /$ mouse) according to Zisman et al. (2000).

\section{Measurement of serum parameters}

Blood samples were measured using the AccuChek Blood Glucose Monitoring System. Up to $100 \mu$ l blood was collected from mice after an overnight fast and serum stored at $-80^{\circ} \mathrm{C}$. Serum triglycerides and free fatty acids were measured using the commercially available kits (Biostat, Stockport, UK; Wako Diagnostic Systems, Neuss, Germany). Serum insulin was measured by ELISA assay (Crystal Chem Inc., Downers Grove, IL, USA).

\section{Preparation of tissue lysates and subcellular fractions}

After an overnight fast, mice were killed by concussion followed by cervical dislocation, and tissues were rapidly extracted and freeze clamped in liquid nitrogen before being stored at $-80{ }^{\circ} \mathrm{C}$. Tissues were ground to a fine powder under liquid nitrogen. Skeletal muscle was obtained from whole hind limbs unless otherwise stated and ground under liquid nitrogen. The pulverised tissues were homogenised in $10 \mathrm{vol} / \mathrm{g}$ ice-cold $50 \mathrm{mM}$ Tris-HCl (pH 7.5), $150 \mathrm{mM} \mathrm{NaCl}, 2 \mathrm{mM}$ EGTA, $2 \mathrm{mM}$ EDTA, $5 \%$ (v/v) glycerol, $0 \cdot 1 \%(\mathrm{v} / \mathrm{v})$ 2-mercaptoethanol, 'complete' protease inhibitor cocktail (Buffer A) plus $0 \cdot 1 \%(\mathrm{v} / \mathrm{v})$ Triton X-100 and $1 \mu \mathrm{M}$ microcystin-LR (Life Technologies), using a Polytron PT-1200 and centrifuged at $16000 \mathrm{~g}$ for $10 \mathrm{~min}$ at $4{ }^{\circ} \mathrm{C}$. The supernatant (lysate) was snap-frozen in liquid nitrogen and stored at $-80^{\circ} \mathrm{C}$.

For phosphorylase kinase assays, mice were terminally anaesthetised for $20 \mathrm{~min}$ by an i.p. injection of $60 \mu \mathrm{g} / \mathrm{g}$ pentobarbital followed by a further injection of $40 \mu \mathrm{g} / \mathrm{g}$ propranolol to inhibit the effects of adrenaline. Skeletal muscle was harvested 30-90 min after propranolol administration and homogenised in $10 \mathrm{vol} / \mathrm{g}$ ice-cold $50 \mathrm{mM}$ Tris-HCl (pH 7.5), 2 mM EDTA, 20 mM EGTA, $1 \mathrm{mM}$ sodium orthovanadate, $50 \mathrm{mM} \mathrm{NaF}, 5 \mathrm{mM}$ pyrophosphate, $0 \cdot 1 \%(\mathrm{v} / \mathrm{v})$ Triton X-100, $1 \mu \mathrm{M}$ microcystin-LR, $0 \cdot 1 \% \quad(\mathrm{v} / \mathrm{v})$ 2-mercaptoethanol and 'complete' protease inhibitor cocktail.

For preparation of membrane and cytosolic fractions, frozen ground skeletal muscle was homogenised in $4-6 \mathrm{vol} / \mathrm{g}$ buffer $\mathrm{A}$. The homogenates were centrifuged at $1000 \mathrm{~g}$ for $10 \mathrm{~min}$ at $4{ }^{\circ} \mathrm{C}$ to remove nuclei, and the supernatant was centrifuged at $100000 \mathrm{~g}$ for $1 \mathrm{~h}$ at $4^{\circ} \mathrm{C}$. The $100000 \mathrm{~g}$ supernatant (termed cytoplasmic fraction) was snap-frozen and stored at $-80^{\circ} \mathrm{C}$. The pellet (termed membrane fraction) was washed twice in ice-cold Buffer A with repeated centrifugation at $100000 \mathrm{~g}$ for $30 \mathrm{~min}$, and finally resuspended in $300 \mu \mathrm{l}$ ice-cold buffer A containing $1 \%$ Triton $\mathrm{X}-100$. This lysate was snapfrozen and stored at $-80^{\circ} \mathrm{C}$.

\section{Enzyme assays and glycogen content}

Phosphorylase kinase was assayed using the peptide KRKQISVRGLA (residues 10-20 of human muscle phosphorylase $b$ ) as a substrate. Skeletal muscle lysate (50-100 $\mu \mathrm{g})$ diluted in $100 \mu \mathrm{l} 50 \mathrm{mM}$ Tris-HCl (pH $7 \cdot 5), 150 \mathrm{mM} \mathrm{NaCl}, 0 \cdot 1 \%$ (v/v) 2-mercaptoethanol, 'complete' protease inhibitor cocktail was incubated for $1 \mathrm{~h}$ at $4{ }^{\circ} \mathrm{C}$ on a shaking platform with $30 \mu \mathrm{g}$ anti-PhK antibody non-covalently coupled to $10 \mu \mathrm{l}$ protein G-Sepharose. Following centrifugation for $1 \mathrm{~min}$ at $16000 \mathrm{~g}$, the pellets were washed twice with $0.5 \mathrm{ml}$ $50 \mathrm{mM}$ Tris-HCl (pH 7.5), $500 \mathrm{mM} \mathrm{NaCl}, 0 \cdot 1 \%$ (v/v) 2-mercaptoethanol and once with $50 \mathrm{mM}$ Tris-HCl $(\mathrm{pH}$ $7 \cdot 5), 0 \cdot 1 \%(\mathrm{v} / \mathrm{v})$ 2-mercaptoethanol. The pellet was assayed for $\mathrm{PhK}$ activity in $50 \mu \mathrm{l} 50 \mathrm{mM}$ Tris- $\mathrm{HCl}$, $50 \mathrm{mM}$ sodium-2-glycerophosphate $\mathrm{pH} 8 \cdot 6$ or $\mathrm{pH} 6 \cdot 8$, $2.5 \mu \mathrm{M}$ cyclic-AMP-dependent protein kinase inhibitor (TTYADFIASGRTGRRNAIHD), $10 \mathrm{mM}$ magnesium acetate, $100 \mathrm{nM}$ okadaic acid, $0 \cdot 1 \% \quad(\mathrm{v} / \mathrm{v})$ 2-mercaptoethanol, $0 \cdot 1 \mathrm{mM}\left[\gamma_{-}{ }^{32} \mathrm{P}\right]$ ATP, $0 \cdot 5 \mathrm{mg} / \mathrm{ml}$ $(\sim 400 \mu \mathrm{M})$ phosphorylase $b$ peptide and $0.04 \mathrm{mM}$ $\mathrm{CaCl}_{2}$. Assays were performed for $20 \mathrm{~min}$ at $30^{\circ} \mathrm{C}$ with constant agitation and were terminated by spotting $40 \mu \mathrm{l}$ onto Whatman P81 paper, followed by immersion in $75 \mathrm{mM}$ phosphoric acid. Papers were washed for $4 \times$ $15 \mathrm{~min}$ in $75 \mathrm{mM}$ phosphoric acid, once briefly in water and then acetone. ${ }^{32} \mathrm{P}$ incorporation was determined by Cerenkov counting on a liquid scintillation counter. One unit (U) of kinase activity is defined as that which catalyses the incorporation of $1 \mu$ mole of ${ }^{32} \mathrm{P}$ into substrate peptide per minute.

AMPK $\alpha 1$ and $\alpha 2$ activities were assayed by Ser phosphorylation of the peptide substrate AMARAASAAALARRR following isoform-specific immunoadsorption (Sakamoto et al. 2005). Glycogen was measured using the anthrone reagent after extraction from skeletal muscle with $1 \mathrm{~mol} / \mathrm{l} \mathrm{NaOH}$ at $100{ }^{\circ} \mathrm{C}$ for 60 min (Roe \& Dailey 1966).

\section{Statistical analysis}

All data are presented as mean \pm s.E.M. Statistical significance was tested using Student's $t$-test, except where stated otherwise. 


\section{Results}

\section{Phenotypic analysis of $\mathrm{G}_{\mathrm{M}}^{--}$mice backcrossed more than six times onto C57BL/6 and 129s2/sV backgrounds}

The $\mathrm{G}_{\mathrm{M}}^{-1-}$ mice that developed obesity, glucose intolerance and insulin resistance in late adult life (Delibegovic et al. 2003) and lean, glucose-tolerant, insulin-sensitive $\mathrm{G}_{\mathrm{M}}^{-1-}$ mice of Suzuki et al. (2001) were created using 129/ Ola and 129/SvJ mouse embryonic stem cells respectively, backcrossed to the C57BL/ 6 strain and examined after two to three backcrosses. Extensive genetic variability among 129 substrains has been reported (Simpson et al. 1997). Although129/Ola and 129/SvJ are from the same parental lineage, they were separated by a contamination introduced into the Sv and SvJ lines. However, examination of 25 protein markers did not uncover any variation between 129/Ola-Hsd and 129/ $\mathrm{SvJ}$ at the protein level (Simpson et al. 1997). In order to determine whether the different phenotypes of the $\mathrm{G}_{\mathrm{M}}^{-1-}$ mouse models reside in the different genetic backgrounds of the 129 substrains used to create them, the obese, glucose-intolerant, insulin-resistant $\mathrm{G}_{\mathrm{M}}^{-1-}$ mice of Delibegovic et al. (2003) were further backcrossed onto a C57BL/ 6 background. After at least six backcrosses, the mice, as expected, had no $\mathrm{G}_{\mathrm{M}}$ protein in skeletal muscle detectable by immunoblotting and low PP1 $\beta$ levels (Fig. 1A) as observed previously for $\mathrm{G}_{\mathrm{M}}^{-1-}$ mice (Delibegovic et al. 2003). However, they showed no significant difference in weights or abdominal fat from $\mathrm{G}_{\mathrm{M}}^{+/+}$mice up to 12 months of age (and hence are termed lean C57BL/ $6 \mathrm{G}_{\mathrm{M}}^{-1-}$ mice, Fig. 1B) in contrast to the obese $\mathrm{G}_{\mathrm{M}}^{-/-}$mice examined earlier, which showed increased weights of $\sim 20 \%$ at 12 months of age with increased fat deposition. The glucose tolerance and insulin sensitivity in the lean $\mathrm{C} 57 \mathrm{BL} / 6 \mathrm{G}_{\mathrm{M}}^{-1-}$ mice were not statistically different from $\mathrm{G}_{\mathrm{M}}^{+/+}$controls (Fig. 1C and D) in contrast to the obese $\mathrm{G}_{\mathrm{M}}^{-{ }^{-}}$mice that were glucose intolerant and insulin resistant at 11-12 months of age.

129/Ola mice breed poorly and were not available for backcrossing. We therefore crossed the obese $\mathrm{G}_{\mathrm{M}}^{-1-}$ mice onto a related $129 \mathrm{~s} 2 / \mathrm{sV}$ background. After more than six backcrosses, the $129 \mathrm{~s} 2 / \mathrm{sV} \mathrm{G}_{\mathrm{M}}^{-1-}$ mice showed no increase in body weight or abdominal fat compared with $129 \mathrm{~s} 2 / \mathrm{sV} \mathrm{G}_{\mathrm{M}}^{+/+}$mice up to 12 months of age (Fig. 1E). Glucose tolerance and insulin sensitivity in mice of more than 12 months of age was similar to that of controls (Fig. 1F and G).

No significant differences in fasting blood glucose levels were observed in lean $\mathrm{C} 57 \mathrm{BL} / 6 \mathrm{G}_{\mathrm{M}}^{-1-}$ mice compared with $\mathrm{C} 57 / \mathrm{BL} / 6 \mathrm{G}_{\mathrm{M}}^{+/+}$mice (Table 1), obese $\mathrm{G}_{\mathrm{M}}^{-/}$mice compared with control $\mathrm{G}_{\mathrm{M}}^{+/+}$littermates (Delibegovic et al. 2003) or $129 \mathrm{~s} 2 / \mathrm{sV} \mathrm{G}_{\mathrm{M}}^{-1-}$ mice compared with $129 \mathrm{~s} 2 / \mathrm{sV} \mathrm{G}_{\mathrm{M}}^{+++}$controls (data not shown). Fasting plasma triglycerides of lean $\mathrm{C} 57 \mathrm{Bl} / 6$
$\mathrm{G}_{\mathrm{M}}^{-1-}$ mice were also similar to $\mathrm{C} 57 \mathrm{BL} / 6$ controls (Table 1 ), but the triglyceride levels of obese $\mathrm{G}_{\mathrm{M}}^{-/-}$ mice showed a $1 \cdot 6$-fold increase over C57BL/ 6 control levels $\left(\mathrm{C} 57 \mathrm{BL} / 6 \mathrm{G}_{\mathrm{M}}^{+/+} 42 \cdot 8 \pm 3 \cdot 6 \mathrm{mg} / \mathrm{dl}\right.$ versus obese $\left.\mathrm{G}_{\mathrm{M}}^{-/-} 68.9 \pm 12.5 \mathrm{mg} / \mathrm{dl} ; n=4\right)$ at $2-5$ months of age, suggesting that triglyceride increase may contribute to the development of obesity in these mice during the early stages. Serum-free fatty acids and serum insulin levels of lean $\mathrm{C} 57 \mathrm{BL} / 6 \mathrm{G}_{\mathrm{M}}^{-1-}$ mice showed a tendency towards lower and higher levels respectively than controls, but the differences were not statistically significant.

\section{Analysis of the effects of environmental factors on lean C57BL/6 $\mathrm{G}_{\mathrm{M}}^{-1-}$ mice}

Environmental factors such as the composition of the diet and total food intake could also underlie the differences between the two models of $\mathrm{G}_{\mathrm{M}}^{-1-}$ mice. However, the food intake of lean C57BL/ $6 \mathrm{G}_{\mathrm{M}}^{-1-}$ mice was similar to that of $\mathrm{C} 57 \mathrm{BL} / 6 \mathrm{G}_{\mathrm{M}}^{+/+}$controls (data not shown) and previous studies showed that the food intake of obese $\mathrm{G}_{\mathrm{M}}^{-1-}$ mice was similar to the food intake of control mice (Delibegovic et al. 2003). Since the $\mathrm{G}_{\mathrm{M}}^{-/-}$ mice are defective in the conversion of glucose to glycogen in skeletal muscle, we examined the effects of increasing glucose levels in the diets. After addition of $30 \%$ glucose to the diet of lean C57BL $/ 6 \mathrm{G}_{\mathrm{M}}^{-1-}$ and control C57BL/ $6 \mathrm{G}_{\mathrm{M}}^{+/+}$mice from weaning to 6 months of age followed by a diet of standard chow, glucose tolerance of the $\mathrm{G}_{\mathrm{M}}^{-1-}$ mice was not significantly different from that of the controls at 8 (Fig. 2A) and 12 months of age (Fig. 2B). Insulin sensitivity in the $\mathrm{C} 57 \mathrm{BL} / 6 \mathrm{G}_{\mathrm{M}}^{-1-}$ and control mice was similar at 12 months of age (data not shown). A high-protein, lowcarbohydrate diet also did not modulate glucose tolerance or insulin resistance (data not shown).

\section{Biochemical analyses of lean $\mathrm{C} 57 \mathrm{BL} / 6 \mathrm{G}_{\mathrm{M}}^{--}$mice}

Genetically determined biochemical variation may account for the different phenotypes of the $\mathrm{G}_{\mathrm{M}}^{-1-}$ mice and therefore biochemical analyses were performed on lean $\mathrm{C} 57 \mathrm{BL} / 6 \mathrm{G}_{\mathrm{M}}^{-1-}$ mice. Glycogen levels in skeletal muscle of lean C57BL/ $6 \mathrm{G}_{\mathrm{M}}^{-1-}$ mice were low ( $\sim 30 \%$ of controls; Fig. 3A), although not as low as those observed in the obese $\mathrm{G}_{\mathrm{M}}^{-/-}$mice $(\sim 10 \%$ of controls; Delibegovic et al. 2003). The activity ratios of the $\mathrm{PP} 1-\mathrm{G}_{\mathrm{M}}$ substrates, phosphorylase $(-/+$ AMP) and GS $(-/+$ G6P) were increased and decreased respectively compared with controls, similarly to ratios observed for the obese $\mathrm{G}_{\mathrm{M}}^{-1-}$ mice (Delibegovic et al. 2003, Toole \& Cohen 2007). Phosphorylase kinase (PhK), an in vitro substrate of PP1- $G_{M}$, was investigated by an immunoadsorption assay. The specificity of this new assay was demonstrated 

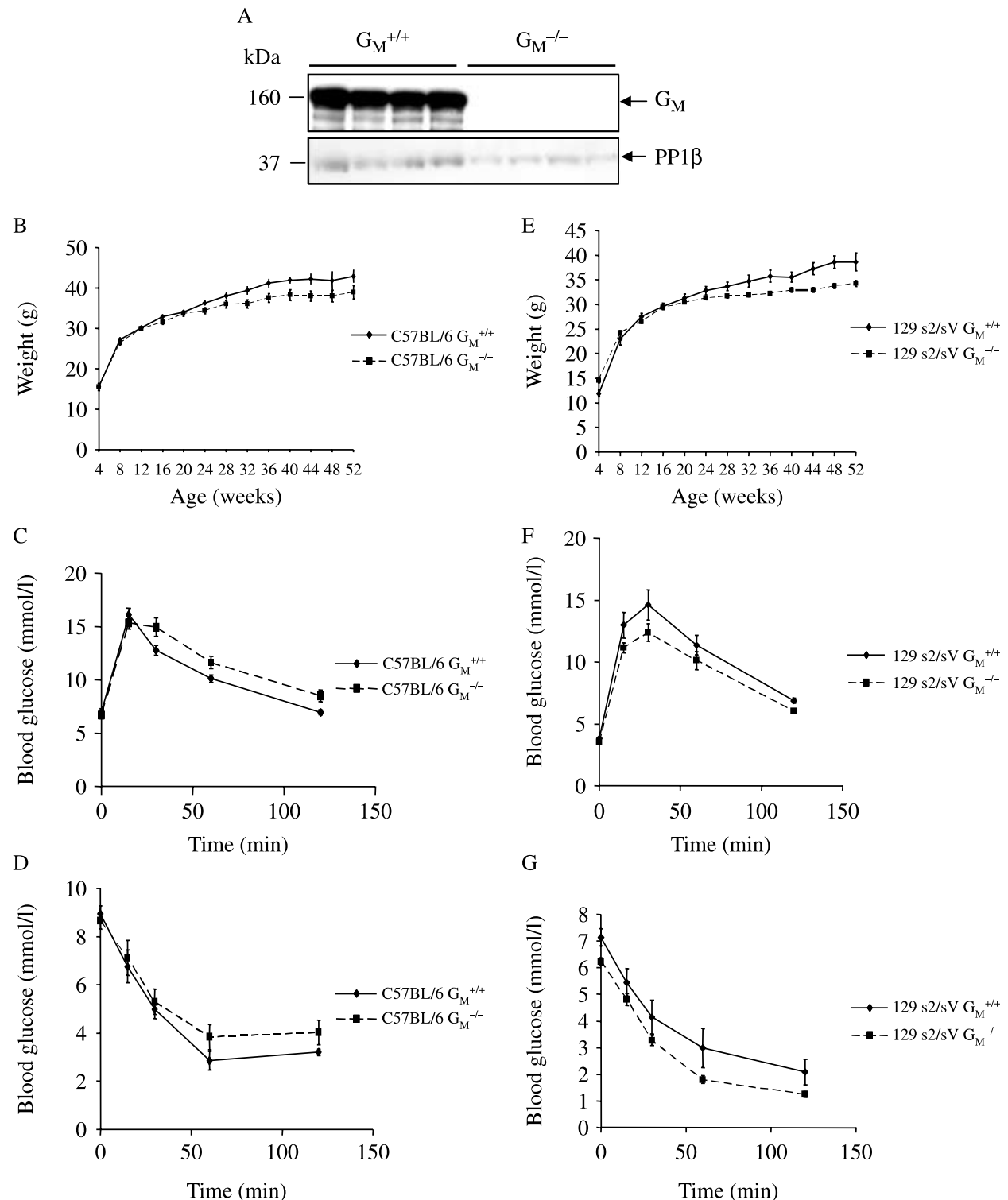

G

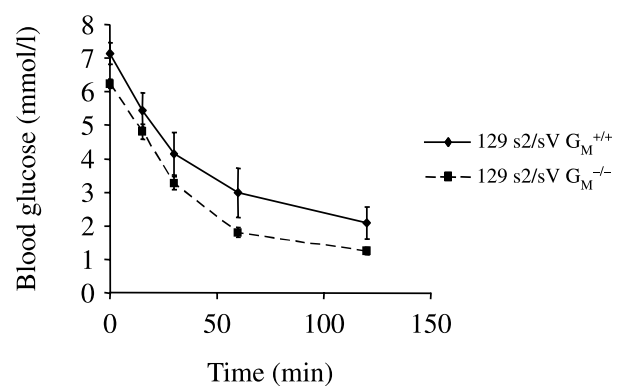

Figure 1 (A) Immunoblot showing $G_{M}$ protein levels and PP1 $\beta$ levels in skeletal muscle from fasted C57BL/6 $\mathrm{G}_{M}^{+/+}$and $\mathrm{C} 57 \mathrm{BL} / 6 \mathrm{G}_{M}^{-1-}$ mice. $\mathrm{G}_{M}$ and PP1 $\beta$ were visualised using anti- $\mathrm{G}_{M}$ and anti-PP1 $\beta$ antibodies. $\mathrm{G}_{M}(121 \mathrm{kDa})$ migrates at $\sim 160 \mathrm{kDa}$ on SDS polyacrylamide gels. (B) Weights of male $\mathrm{G}_{\mathrm{M}}^{+/+}$ and $\mathrm{G}_{\mathrm{M}}^{-1-}$ mice backcrossed at least six times onto a background of C57BL/6. Results are the mean \pm S.E.M. for $12 \mathrm{G}_{\mathrm{M}}^{+/+}$and $8 \mathrm{G}_{\mathrm{M}}^{-1-}$ mice at each time point. $\mathrm{G}_{\mathrm{M}}^{-1-}$ mice do not have increased weight gain compared with $\mathrm{G}_{\mathrm{M}}^{+++}$mice. (C) Glucose tolerance tests performed on male mice backcrossed at least six times and aged more than 12 months. Results are mean \pm S.E.M. for $8 \mathrm{G}_{\mathrm{M}}^{+/+}$and $11 \mathrm{G}_{\mathrm{M}}^{-1-}$ animals. The blood glucose values for $\mathrm{G}_{\mathrm{M}}^{+/+}$and $\mathrm{G}_{\mathrm{M}}^{-1-}$ mice at $0,15,60$ and 120 min were not significantly different when assessed using Student's $t$-test. (D) Insulin tolerance tests performed on male mice backcrossed at least six times and aged more than 12 months. Results are the mean \pm S.E.M. for $7 \mathrm{G}_{\mathrm{M}}^{+/+}$and $6 \mathrm{G}_{\mathrm{M}}^{-1-}$ animals. The blood glucose values for $\mathrm{G}_{\mathrm{M}}^{+/+}$and $\mathrm{G}_{\mathrm{M}}^{-1-}$ mice are not significantly different at any time point. (E) Weights of male $\mathrm{G}_{\mathrm{M}}^{+/+}$and $\mathrm{G}_{\mathrm{M}}^{-1-}$ animals backcrossed at least six times onto a background of $129 \mathrm{~s} 2 / \mathrm{sV}$. Results are the mean \pm S.E.M. for $7 \mathrm{G}_{\mathrm{M}}^{+/+}$and $16 \mathrm{G}_{\mathrm{M}}^{-1-}$ mice at each time point. $\mathrm{G}_{\mathrm{M}}^{-1-}$ mice do not have increased weight gain compared with $\mathrm{G}_{\mathrm{M}}^{++1}$ mice. $(\mathrm{F})$ Glucose tolerance tests performed on male mice backcrossed at least six times onto $129 \mathrm{~s} 2 / \mathrm{sV}$ and aged more than 12 months. Results are mean \pm S.E.M. for $6 \mathrm{G}_{\mathrm{M}}^{+/+}$and $15 \mathrm{G}_{\mathrm{M}}^{-1-}$ mice. The blood glucose values for $\mathrm{G}_{\mathrm{M}}^{+/+}$and $\mathrm{G}_{\mathrm{M}}^{-1-}$ mice at 0,60 and $120 \mathrm{~min}$ are not significantly different. $(G)$ Insulin tolerance tests performed on male mice backcrossed at least six times onto $129 \mathrm{~s} 2 / \mathrm{sV}$ and aged more than 12 months. Results are mean \pm S.E.M. for $6 \mathrm{G}_{\mathrm{M}}^{+/+}$and $15 \mathrm{G}_{\mathrm{M}}^{-1-}$ mice of each genotype. $\mathrm{G}_{\mathrm{M}}^{-1-}$ mice do not have significantly decreased insulin sensitivity. 
Table 1 Levels of blood components in C57BL/ $6 \mathrm{G}_{\mathrm{M}}^{+/+}$and lean C57BL/ $6 \mathrm{G}_{\mathrm{M}}^{-1}$

\begin{tabular}{|c|c|c|}
\hline & C57BL/6 $\mathrm{G}_{\mathrm{M}}^{+/+}$ & C57BL / $6 \mathrm{G}_{\mathrm{M}}^{-1-}$ \\
\hline \multicolumn{3}{|l|}{ Blood component } \\
\hline $\begin{array}{l}\text { Fasting blood glucose } \\
(\mathrm{mmol} / \mathrm{l})\end{array}$ & $6 \cdot 68 \pm 0 \cdot 353(9)$ & $7 \cdot 25 \pm 0 \cdot 354(6)$ \\
\hline $\begin{array}{l}\text { Fasting serum } \\
\text { triglycerides }(\mathrm{mg} / \mathrm{dl})\end{array}$ & $67 \cdot 4 \pm 9 \cdot 4(7)$ & $68 \cdot 5 \pm 12 \cdot 0(5)$ \\
\hline $\begin{array}{l}\text { Fasting serum NEFA } \\
(\mathrm{mmol} / \mathrm{l})\end{array}$ & $1 \cdot 24 \pm 0 \cdot 4(7)$ & $0.85 \pm 0.09(5)$ \\
\hline $\begin{array}{l}\text { Fasting serum insulin } \\
(\mathrm{ng} / \mu \mathrm{l})\end{array}$ & $0.583 \pm 0.228(8)$ & $0.807 \pm 0.176(7)$ \\
\hline
\end{tabular}

Blood samples were obtained from the tail veins of mice aged $6-8$ months. The values for $\mathrm{G}_{\mathrm{M}}^{-1-}$ versus $\mathrm{G}_{\mathrm{M}}^{+/+}$mice were not significantly different using Student's $t$-test for any component. The numbers of mice tested are given in brackets. NEFA denotes non-esterified fatty acids. The fasting serum insulin levels were also not significantly different when assessed using the Mann-Whitney-Wilcoxon $U$ test.

by showing that no activity was present in the skeletal muscle of I/ICR PhK-deficient mice (Cohen \& Cohen 1973; Fig. 3B, left panel). Increased $\mathrm{PhK}$ activity at $\mathrm{pH}$ 6.8 in the skeletal muscle lysates of anaesthetised propranolol-treated lean $\mathrm{C} 57 \mathrm{BL} / 6 \quad \mathrm{G}_{\mathrm{M}}^{-1-}$ mice was observed compared with controls (Fig. 3B, right panel). The use of propranolol prevented inadvertent activation of PhK in response to adrenalin, because the latter may take up to $90 \mathrm{~min}$ to decline to zero (Toole \& Cohen 2007). In contrast to the $\mathrm{pH} 6.8$ activity, the PhK activity at $\mathrm{pH} 8 \cdot 6$, which is a measure of the total activity, was similar in lean $\mathrm{C} 57 \mathrm{BL} / 6 \mathrm{G}_{\mathrm{M}}^{-1-}$ and control mice. Activation of $\mathrm{PhK}$ at $\mathrm{pH} 6.8$ has been linked with phosphorylation of the enzyme (Krebs 1972) and correlated with phosphorylation of a specific serine in a peptide of the $\beta$-subunit of PhK (Stewart et al. 1981), identified as Ser26 (Kilimann et al. 1988). Our data therefore imply that the $\beta$-subunit is hyperphosphorylated on Ser26 and are consistent with PhK being an in vivo substrate of PP1- $\mathrm{G}_{\mathrm{M}}$. The $\mathrm{pH} 6 \cdot 8 / 8 \cdot 6$ activity was 0.53 and $0 \cdot 19$ for lean $\mathrm{C} 57 \mathrm{BL} / 6 \mathrm{G}_{\mathrm{M}}^{-/-}$and control mice respectively.

The insulin-sensitive kinase cascade leading to the activation of GS was functional in the skeletal muscle of lean $\mathrm{C} 57 \mathrm{BL} / 6 \mathrm{G}_{\mathrm{M}}^{-1-}$ mice (Fig. 3C) similarly to obese $\mathrm{G}_{\mathrm{M}}^{-1-}$ mice (Delibegovic et al. 2003). PKB is activated in response to insulin by phosphorylation on Thr308, which in turn inhibits GSK3 $\alpha$ and GSK3 $\beta$ by phosphorylation of Ser21 and Ser 9 respectively. PKB, GSK $3 \alpha$ and GSK3 $\beta$ were phosphorylated similarly to controls in the skeletal muscle of lean $\mathrm{C} 57 \mathrm{BL} / 6 \mathrm{G}_{\mathrm{M}}^{-1-}$ mice in response to insulin (Fig. 3C); GSK3 $\alpha$ and GSK3 $\beta$ also responded similarly to insulin in the skeletal muscle of obese $\mathrm{G}_{\mathrm{M}}^{-/-}$and control mice (Delibegovic et al. 2003).

Since energy derived from glycogen is decreased in $\mathrm{G}_{\mathrm{M}}^{-l-}$ mice, we analysed AMPK, which is a sensor of cellular energy (Hardie et al. 2006). The activity of the AMPK $\alpha 1$ isoform was similar in the skeletal muscle of C57BL/ $6 \mathrm{G}_{\mathrm{M}}^{+/+}$, lean $\mathrm{C57BL} / 6 \mathrm{G}_{\mathrm{M}}^{-/-}$and obese $\mathrm{G}_{\mathrm{M}}^{-/-}$ mice, but the activity of the AMPK $\alpha 2$ isoform was more than threefold higher in lean $\mathrm{C} 57 \mathrm{BL} / 6 \mathrm{G}_{\mathrm{M}}^{-1-}$ mice than in controls (Fig. 4A) and twofold higher in obese $\mathrm{G}_{\mathrm{M}}^{-1-}$ mice than in controls (data not shown). Consistent with the increase in AMPK $\alpha 2$ activity, phosphorylation of Thr172 in AMPK $\alpha 2$ was increased, while no increase in phosphorylation of AMPKal was observed (Fig. 4B). The level of total AMPK (both $\alpha 1+\alpha 2$ ) was similar in all lines as judged by immunoblotting. A downstream target of AMPK is acetyl-CoA carboxylase (ACC) that can be activated by phosphorylation. The levels of ACC in mouse skeletal muscle were extremely low as judged by immunoblotting, but there was no clear increase in phosphorylation of ACC Ser212 in the total hind limb muscle of lean $\mathrm{C} 57 \mathrm{BL} / 6 \mathrm{G}_{\mathrm{M}}^{-1-}$ mice compared with controls (data not shown) or in the gastrocnemius muscle, which had slightly higher levels of ACC (Fig. 4C).
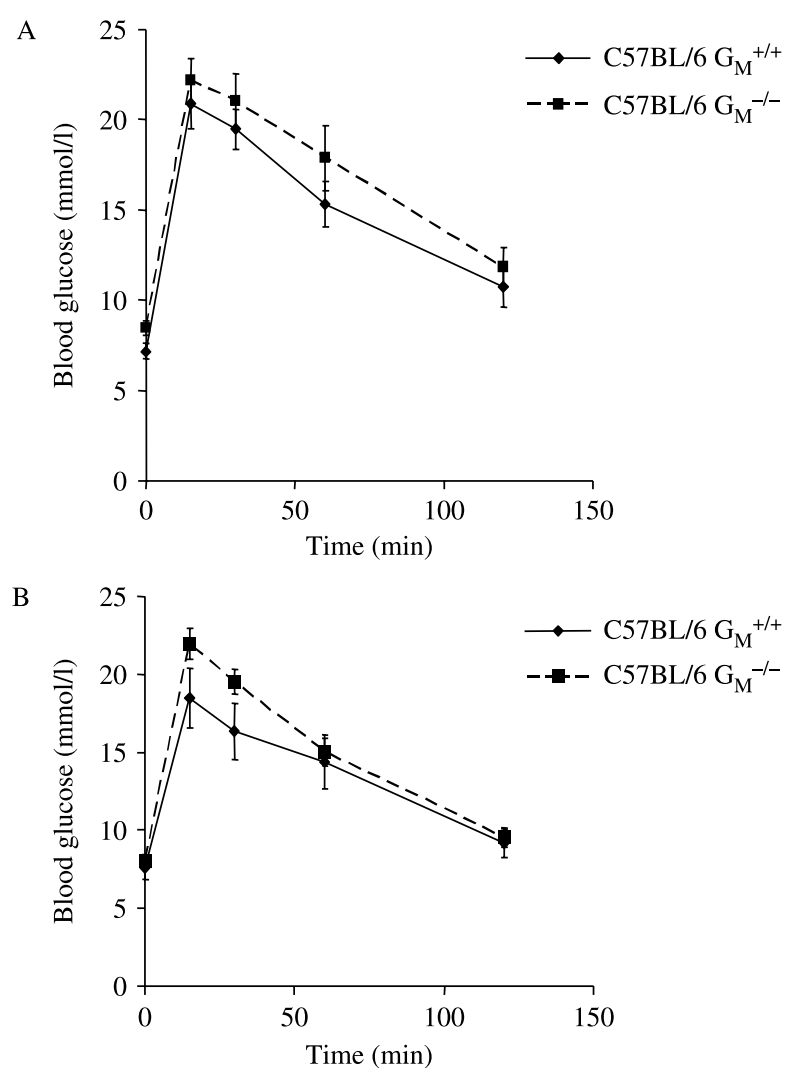

Figure 2 Glucose tolerance tests performed on male C57BL/6 mice born after at least six backcrosses and fed a diet containing $30 \%$ extra glucose from weaning to 6 months, then a standard chow diet for either 2 months (A) or 6 months (B). Results are mean \pm S.E.M. for $11 \mathrm{G}_{\mathrm{M}}^{+/+}$and $17 \mathrm{G}_{\mathrm{M}}^{-1-}$ animals. The blood glucose values for $\mathrm{G}_{\mathrm{M}}^{+/+}$and $\mathrm{G}_{\mathrm{M}}^{-1-}$ mice are not significantly different at any time point in $(A)$ or $(B)$. 
A

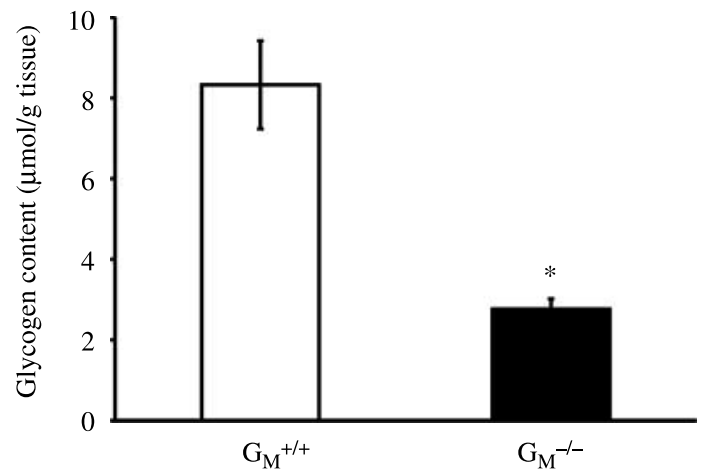

B

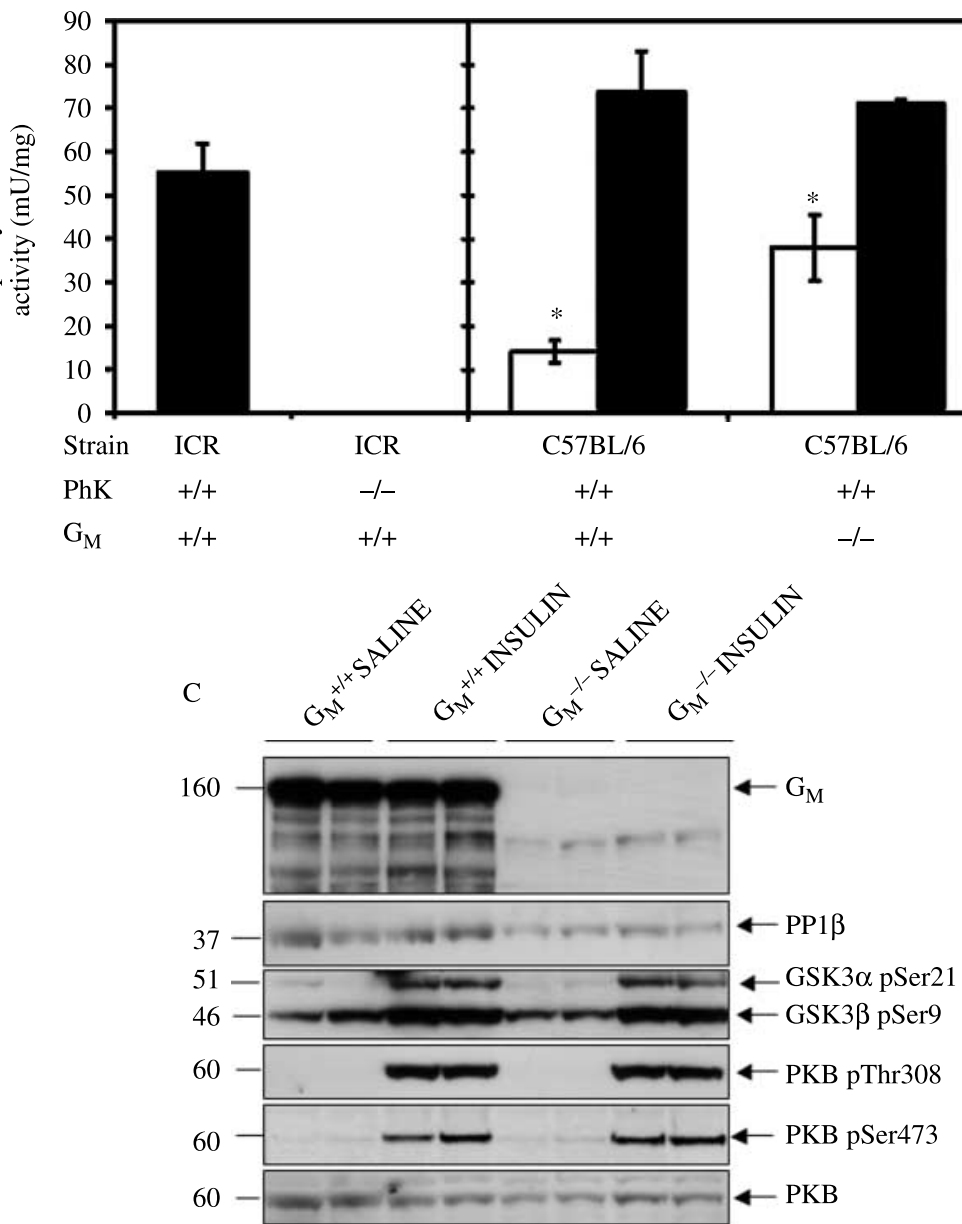

Figure 3 (A) Glycogen content in skeletal muscle of C57BL/6 $\mathrm{G}_{\mathrm{M}}^{+/+}$and lean C57BL/6 $\mathrm{G}_{\mathrm{M}}^{-1-}$ mice fasted overnight. Glycogen concentration is expressed in micromoles of glycosyl units per gram of muscle (wet weight). Results are expressed as the mean \pm S.E.M. for $6 \mathrm{G}_{M}^{+/+}$and $11 \mathrm{G}_{\mathrm{M}}^{-1-}$ animals and the difference between $\mathrm{G}_{\mathrm{M}}^{-1-}$ versus $\mathrm{G}_{\mathrm{M}}^{+/+}$is statistically significant. ${ }^{*} P<0 \cdot 001$. (B) Left panel: Phosphorylase kinase activity at pH 8.6 (in the presence of $40 \mu \mathrm{M} \mathrm{Ca}^{2+}$ ) in skeletal muscle lysates from wild-type ICR and PhK-deficient ICR/I mice. Results are expressed as mean \pm S.E.M. for three $\mathrm{PhK}^{+/+}$and three $\mathrm{PhK}^{-1-}$ mice. Right panel: PhK activity in skeletal muscle lysates from C57BL/6 $\mathrm{G}_{\mathrm{M}}^{+/+}$and lean $\mathrm{C} 57 \mathrm{BL} / 6 \mathrm{G}_{\mathrm{M}}^{-1-}$ mice. Assays were performed in the presence of $40 \mu \mathrm{M} \mathrm{Ca}^{2-}$ at $\mathrm{pH} 6.8$ (near physiological pH, open bars) and $\mathrm{pH} 8.6$ (solid bars). Results are expressed as mean \pm s.E.M. for three to five animals of each genotype. ${ }^{*}$ The difference in pH $6.8 \mathrm{PhK}$ activities of $\mathrm{C} 57 \mathrm{BL} / 6 \mathrm{G}_{\mathrm{M}}^{+/+}$and lean $\mathrm{C} 57 \mathrm{BL} / 6 \mathrm{G}_{\mathrm{M}}^{-1-}$ mice was statistically significant, $P<0.05$. All assays were performed in triplicate. Control values (1-2 $\mathrm{mU} / \mathrm{mg}$ ) using preimmune IgG in place of anti-PhK antibody were subtracted from the calculated activities. (C) Proteins in the PKB insulin signalling pathway in C57BL/6 $\mathrm{G}_{\mathrm{M}}^{+/+}$and lean C57BL/6 $\mathrm{G}_{\mathrm{M}}^{-1-}$ skeletal muscle lysates. Mice were fasted overnight before injection of a bolus of either saline or insulin. Immunoblotting was performed using the indicated antibodies. 


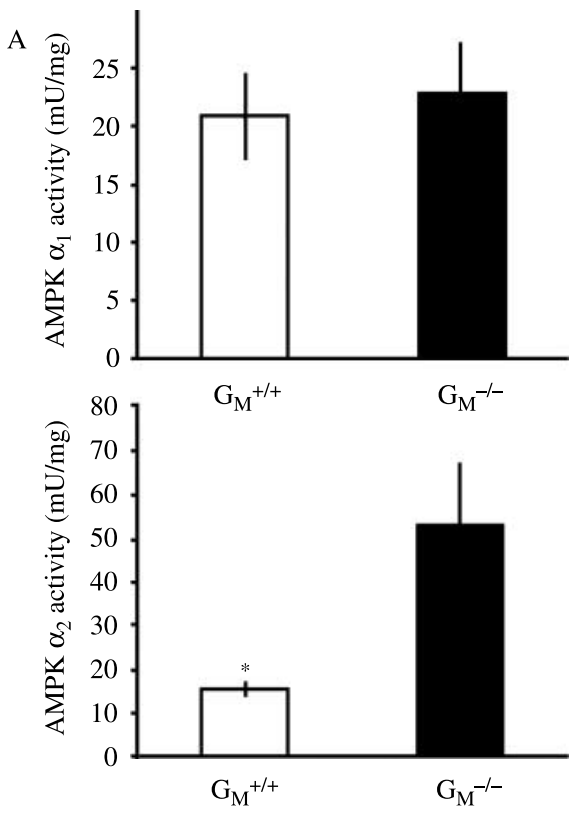

B

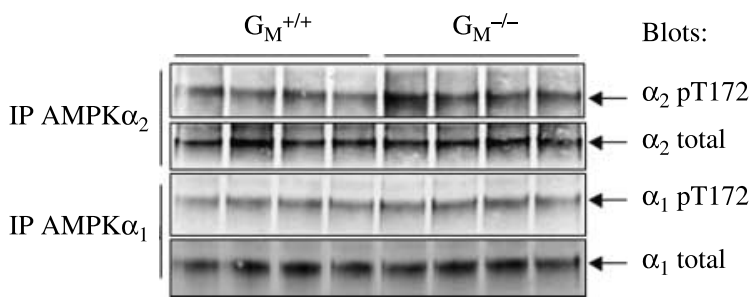

$\mathrm{C}$

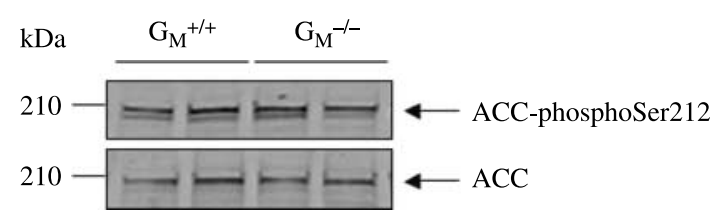

Figure 4 (A) Activities of AMPK $\alpha 1$ and AMPK $\alpha 2$ isoforms in skeletal muscle lysates from five $\mathrm{C} 57 \mathrm{BL} / 6 \mathrm{G}_{\mathrm{M}}^{+/+}$and seven lean $\mathrm{C} 57 \mathrm{BL} / 6$ $\mathrm{G}_{M}^{-1}$ animals. Activities of AMPK $\alpha 1$ are not significantly different. For AMPK $\alpha 2$ activities, statistical significance (*) for $G_{M}^{-1-}$ versus $G_{M}^{+1+}$ was $P<0.05$. (B) AMPK $\alpha 1$ or $\alpha 2$ was immunoprecipitated from lysates of $\mathrm{G}_{\mathrm{M}}^{+/+}$or $\mathrm{G}_{\mathrm{M}}^{-1-}$ mice and immunoblotted with antibodies against the total proteins and phospho-Thr172. (C) Equal amounts of protein $(70 \mu \mathrm{g})$ from lysates of the gastrocnemius muscle of $\mathrm{C} 57 \mathrm{BL} / 6 \mathrm{G}_{\mathrm{M}}^{+/+}$and lean $\mathrm{C} 57 \mathrm{BL} / 6 \mathrm{G}_{\mathrm{M}}^{-1-}$ mice were immunoblotted with the indicated antibodies. ACC phosphorylation was assessed relative to the level of total ACC by quantitative Li-Cor analysis. The ratio ACC phospho-212/total ACC was 1.6 for lean C57BL/6 $\mathrm{G}_{\mathrm{M}}^{-1-}$ mice and 1.6 for the control mice.

The uptake of glucose into skeletal muscle in vivo was decreased in obese $\mathrm{G}_{\mathrm{M}}^{-1-}$ mice compared with controls (Delibegovic et al. 2003) but found to be slightly increased in lean $\mathrm{C} 57 \mathrm{BL} / 6 \mathrm{G}_{\mathrm{M}}^{-/-}$mice compared with controls (Fig. 5). Since AMPK may modulate glucose transport through the insulin-stimulated glucose transporter GLUT4, we analysed GLUT4 and hexokinase II (HKII), which catalyses conversion of the intracellular glucose to glucose-6-phosphate in skeletal muscle. No change in the level of HKII was observed in lean $\mathrm{C} 57 \mathrm{BL} / 6 \mathrm{G}_{\mathrm{M}}^{-/-}$compared with $\mathrm{C} 57 \mathrm{BL} / 6 \mathrm{G}_{\mathrm{M}}^{+/+}$mice (Fig. 6A). Of three commercial anti-GLUT4 antibodies, no two antibodies recognised the same 40-50 kDa band in mouse skeletal muscle lysates (prepared in the presence of the detergent Triton X-100 to solubilise GLUT4). Membrane fractions, which would be expected to contain GLUT4, were then prepared and GLUT4 was again released using Triton X-100. Following immunoadsorption of GLUT4 from the lysates (Fig. 6B) or membrane fractions (Fig. 6C) with an antibody raised to the 15 C-terminal amino acids of GLUT4 (Abcam), a $46 \mathrm{kDa}$ band could be recognised by the same antibody and also by a monoclonal antibody 1F8 raised against partially purified GLUT4containing vesicles (Biogenesis; Fig. 6C). The precise 1F8 antibody epitope is not known but it lies in the cytoplasmic portion of GLUT4 (James et al. 1988, Imamura et al. 2001). The $46 \mathrm{kDa}$ protein was present in the membrane fraction and not in the cytosolic fraction as might be expected for GLUT4. Although immunoblotting of the immunopellets resulted in some variation between samples, there was no clear difference in the levels of GLUT4 in the membrane fractions from whole hind limb muscles, the quadriceps muscle or the gastrocnemius muscle of lean C57BL/6 $\mathrm{G}_{\mathrm{M}}^{-/-}$mice compared with $\mathrm{G}_{\mathrm{M}}^{+/+}$controls (Fig. 6C).

\section{Discussion}

Our studies show that continued backcrossing of the obese, glucose-intolerant, insulin-resistant $\mathrm{G}_{\mathrm{M}}^{-/-}$mice onto two different genetic backgrounds gave rise to lean, glucose-tolerant, insulin-sensitive $\mathrm{G}_{\mathrm{M}}^{-/-}$mice. The loss of the prediabetic phenotype suggests that at least one further variant gene in the 129/Ola background, not present in the C57BL/ 6 or $129 \mathrm{~s} 2 / \mathrm{sV}$ background, may be required for the development of the prediabetic $\mathrm{G}_{\mathrm{M}}^{-l-}$ phenotype. This situation is similar to the interaction of two variant genes underlying severe insulin resistance in the human population (Savage et al. 2002). Environmental changes, including a highfat diet (Suzuki et al. 2001) and high-carbohydrate diet (this study) fed to lean $\mathrm{G}_{\mathrm{M}}^{-1-}$ mice, were insufficient to lead to glucose intolerance and insulin resistance, despite the severely decreased ability of lean $\mathrm{G}_{\mathrm{M}}^{-1-}$ mice to convert glucose to glycogen in skeletal muscle. However, interestingly, mice completely devoid of glycogen in skeletal muscle due to disruption of the muscle GS gene exhibit either normal or improved glucose tolerance (Pederson et al. 2005a). It has been suggested that the reason may be because, in contrast to 

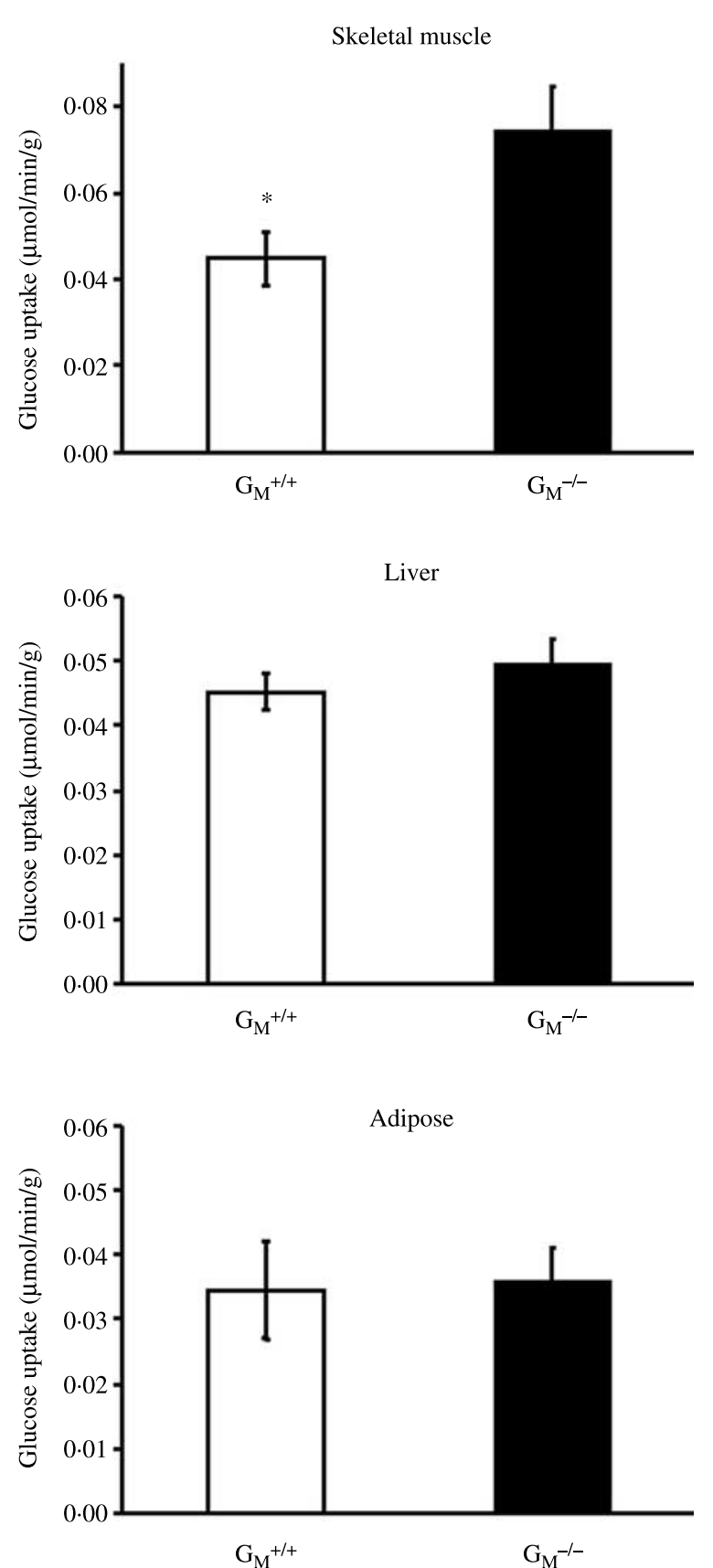

Figure 5 Glucose uptake into the skeletal muscle, liver and adipose tissue of $\mathrm{G}_{\mathrm{M}}^{+++}$and $\mathrm{G}_{\mathrm{M}}^{-1-}$ mice during a glucose tolerance test. A mixture of 2-deoxy-D-[1,2- $\left.{ }^{3} \mathrm{H}\right]$-glucose tracer and unlabelled glucose was injected into six $\mathrm{G}_{\mathrm{M}}^{+/+}$and eight $\mathrm{G}_{\mathrm{M}}^{-1-}$ mice. Data represent the glucose uptake in $\mu \mathrm{mol} / \mathrm{min}$ per $\mathrm{g}$ tissue and are mean values \pm S.E.M. Statistical significance $\left(^{*}\right)$ for the $G_{M}^{-1-}$ versus $\mathrm{G}_{\mathrm{M}}^{+/+}$skeletal muscle glucose uptake was $P<0.05$.

humans who rely on skeletal muscle glycogen for muscle contraction, rodents may be more dependent on liver glycogen stores (Baldwin et al. 1973, Pederson et al. 2005b).

\section{A}

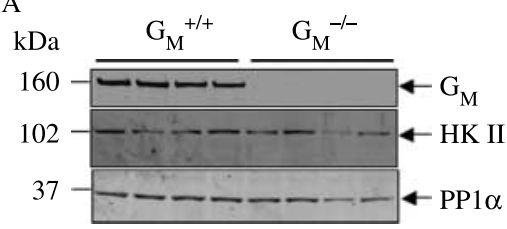

B

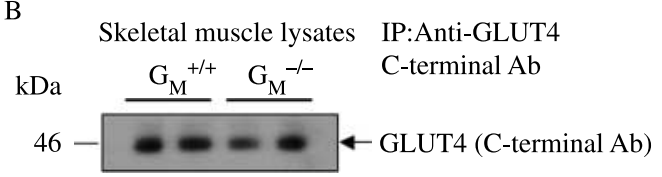

C $\underline{\mathrm{G}_{\mathrm{M}}^{+/+}} \underline{\mathrm{G}_{\mathrm{M}}{ }^{-/-}} \underline{\mathrm{G}_{\mathrm{M}}^{+/+}} \underline{\mathrm{G}_{\mathrm{M}}{ }^{-/-}}$

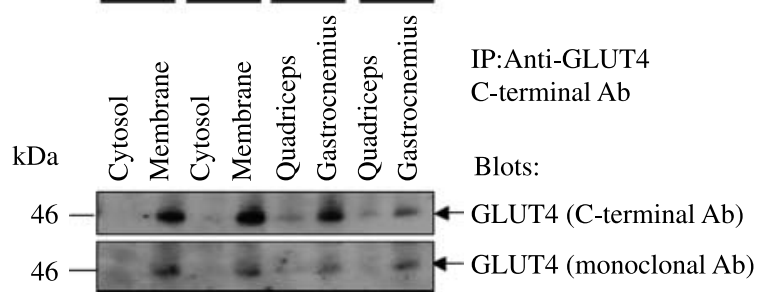

Figure 6 (A) Immunoblots of C57BL/6 $\mathrm{G}_{\mathrm{M}}^{+/+}$and lean C57BL/6 $\mathrm{G}_{\mathrm{M}}^{-1-}$ hind limb skeletal muscle lysates probed with antibodies against $\mathrm{G}_{M}$ and hexokinase II (HKII). (B and C) Covalently coupled anti-GLUT4 C-terminal antibody coupled to protein GSepharose beads was incubated with hind limb skeletal muscle lysates from C57BL/6 $\mathrm{G}_{\mathrm{M}}^{+/+}$and lean C57BL/6 $\mathrm{G}_{\mathrm{M}}^{-1}$ mice. After centrifugation, the immunopellets were subjected to electrophoresis and examined by immunoblotting with the same antiGLUT4 antibody. (C) Immunopellets from purified membrane fractions from the whole hind limbs, the quadriceps and gastrocnemius of $\mathrm{C} 57 \mathrm{BL} / 6 \mathrm{G}_{\mathrm{M}}^{+/+}$and lean $\mathrm{C} 57 \mathrm{BL} / 6 \mathrm{G}_{\mathrm{M}}^{-1-}$ mice were examined similarly (upper blot) and also immunoblotted with a monoclonal anti-GLUT4 antibody (lower blot).

An alternative or additional explanation to the requirement of further variant gene(s) in $\mathrm{G}_{\mathrm{M}}^{-1-}$ mice for the development of insulin resistance is that further backcrossing may lead to compensatory changes that ameliorate the prediabetic phenotype. A comparison of the $\mathrm{C} 57 \mathrm{BL} / 6 \mathrm{G}_{\mathrm{M}}^{-1-}$ mice analysed in this manuscript compared with those in previous studies is presented in Table 2. The glycogen level in the skeletal muscle of the lean $\mathrm{C} 57 \mathrm{BL} / 6 \mathrm{G}_{\mathrm{M}}^{-- \text {- }}$ mice was higher (30\% of controls) than in the obese $\mathrm{G}_{\mathrm{M}}^{-1-}$ mice ( $10 \%$ of controls), but this is unlikely to account for the difference between the lean and obese models because the $\mathrm{G}_{\mathrm{M}}^{-1-}$ mice of Suzuki et al. were lean and had glycogen levels $(10 \%$ of controls) similar to the obese $\mathrm{G}_{\mathrm{M}}^{-1-}$ mice. Other explanations for the obesity include less energy expenditure or a lower metabolic rate. Biochemical analyses revealed that in the skeletal muscle of lean $\mathrm{C} 57 \mathrm{BL} / 6 \mathrm{G}_{\mathrm{M}}^{-1-}$ mice studied in this article the activity of AMPK $\alpha 2$ is increased approximately threefold compared with controls, while the AMPK $\alpha 1$ activities are similar. The low glycogen levels resulting from the 
Table 2 Comparison of the lean C57BL/ $6 \mathrm{G}_{\mathrm{M}}^{-1-}$ mouse model studied in this article with those of Suzuki et al. (2001) and Delibegovic et al. (2003)

Comparison of the $\mathrm{G}_{\mathrm{M}}$ null mouse models

\begin{tabular}{|c|c|c|}
\hline $\begin{array}{l}\text { Paterson et al. (this study) } \\
\text { (Lean C57BL/ } 6 \mathrm{G}_{\mathrm{M}}^{-1} \text { ) }\end{array}$ & $\begin{array}{l}\text { Delibegovic et al. (2003) } \\
\text { (Obese } \mathrm{G}_{\mathrm{M}}^{-1} \text { ) }\end{array}$ & Suzuki et al. (2001) $\left(\mathrm{G}_{\mathrm{M}}^{-1-}\right)$ \\
\hline 129/Ola & 129/Ola & 129/SvJ \\
\hline C57BL/6 (6-10 backcrosses) & C57BL/6 (2-3 backcrosses) & C57BL/6 (2-3 backcrosses) \\
\hline None & None & None \\
\hline$\leq 5 \%$ of control $^{\mathrm{a}}$ & $\leq 5 \%$ of control & ND \\
\hline$\sim 50 \%$ of control ${ }^{\mathrm{a}}$ & $\sim 50 \%$ of control & $\sim 40 \%$ of control \\
\hline Decreased & Decreased & ND \\
\hline $30 \%$ of control & $10 \%$ of control & $10 \%$ of control \\
\hline Normal $^{\mathrm{a}}$ & $\sim 50 \%$ of control & Normal \\
\hline Increased $^{\mathrm{a}}$ & Increased & Increased \\
\hline Hyperphosphorylated $^{a}$ & ND & ND \\
\hline Increased & ND & ND \\
\hline Normal $^{\mathrm{a}}$ & $\sim 50 \%$ of control & $\sim 70 \%$ of control \\
\hline Decreased $^{a}$ & Decreased & Decreased \\
\hline Decreased $^{a}$ & Decreased & No significant change \\
\hline$\sim 2$-fold ${ }^{\mathrm{a}}$ & $\sim 2$-fold & $\sim 2$-fold \\
\hline Hyperphosphorylated $^{a}$ & ND & $N D^{b}$ \\
\hline Normal & Normal & ND \\
\hline Normal & ND & ND \\
\hline Normal & Normal & ND \\
\hline$\sim$ 3-fold increase & $\sim 2$-fold increase & ND \\
\hline Normal & ND & ND \\
\hline Normal & ND & ND \\
\hline Activity normal $^{\mathrm{a}}$ & Activity decreased & R5/PTG level normal \\
\hline Normal & Increased & Normal \\
\hline Normal & Increased & Normal \\
\hline Normal & Normal & Normal \\
\hline Normal & Normal & Normal \\
\hline Normal & Impaired & Normal \\
\hline Normal & Normal & Normal \\
\hline Normal & Insulin resistant & Normal \\
\hline Slightly increased (in vivo) & $\sim 30 \%$ of control (in vivo) & Normal (in vitro, no age stated) \\
\hline
\end{tabular}

\section{Parameter}

\section{Donor strain}

Genetic background

$\mathrm{G}_{\mathrm{M}}$ protein in sk. muscle

PP1-G $\mathrm{G}_{\mathrm{M}}$ activity

PP1c (total PP1 activity)

PP1 $\beta$ level

Sk. muscle glycogen

Phosphorylase total activity

Basal Phosphorylase (-/+AMP) activity ratio

Phosphorylase pSer14

Basal PhK (pH 6.8/pH 8.6) activity ratio

GS total activity

Basal GS $(-/+\mathrm{G} 6 \mathrm{P})$ activity ratio

Insulin-stimulated $\mathrm{GS}(-/+\mathrm{G} 6 \mathrm{P})$ activity ratio

GS stimulation by insulin

GS pSer640, pSer644

GSK3 $\alpha$ pSer21, $\beta$ pSer9 stimulation by insulin

PKB pThr308, pSer473 stimulation by insulin

AMPK $\alpha 1$ activity

AMPK $\alpha 2$ activity

GLUT4 level

HK level

PP1-R5/PTG

Weight gain in mice over 3 months old

Abdominal fat in mice at $\sim 12$ months old

Fasting blood plasma glucose

Glucose tolerance at up to $\sim 8$ months old

Glucose tolerance at $\sim 11$ months old

Insulin sensitivity at up to $\sim 8$ months old

Insulin sensitivity at $\sim 12$ months old

Glucose transport (sk. muscle) at $\sim 12$ months old

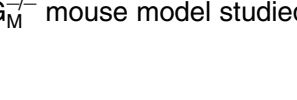

Data for each model are compared with $\mathrm{G}_{\mathrm{M}}^{+/+}$littermates and classified as normal if no significant differences were detected. Enzyme activities and protein levels are assayed in skeletal muscle. Toole \& Cohen (2007)

Hyperphosphorylation reported but sites not identified;

$\mathrm{ND}$, not determined. 
disruption of the $G_{M}$ gene may be expected to lead to decreased ATP production from glycogen and consequent elevation of AMP, leading to the activation of AMPK, which is a sensor of cellular energy levels and has also been proposed to be a sensor of glycogen stores (Hardie \& Sakamoto 2006). One of the downstream actions of AMPK is to phosphorylate and inhibit ACC 2 in skeletal muscle, decreasing the production of malonyl-CoA, an allosteric inhibitor of carnitine palmitoyltransferase 1 . Since the latter enzyme is rate limiting for the entry of long-chain fatty acyl-CoA into the mitochondria for oxidation, relief from inhibition leads to an increase in the oxidation of fatty acids (Saha \& Ruderman 2003, Kahn et al. 2005). Although this mechanism is attractive for allowing fatty acids to be used as an alternative energy source to glycogen in $\mathrm{G}_{\mathrm{M}}^{-1-}$ skeletal muscle, we found no evidence for increased phosphorylation of ACC in the lean $\mathrm{C} 57 \mathrm{BL} / 6 \mathrm{G}_{\mathrm{M}}^{-1-}$ mice, which have an approximately threefold increase in AMPK $\alpha 2$ activity compared with controls. Activation of AMPK by approximately tenfold in skeletal muscle of muscle GS knockout (MGSKO) mice compared with controls elicited only an $\sim 1.5$-fold increase in the phosphorylation state of ACC in MGSKO mice compared with controls (Pederson et al. 2005a) and therefore it is possible that an approximately threefold activation of AMPK is insufficient to cause detectable phosphorylation of ACC.

AMPK also increases the expression of the insulinstimulated glucose transporter GLUT4, which is highly regulated by a number of factors (Zorzano et al. 2005). Nevertheless, following immunoadsorption and centrifugation, immunoblotting of the pellets yielded no clear differences in level of GLUT4 in lysates or membrane fractions of skeletal muscle from fasted lean $\mathrm{C} 57 \mathrm{BL} / 6 \mathrm{G}_{\mathrm{M}}^{-1-}$ mice compared with $\mathrm{G}_{\mathrm{M}}^{+/+}$controls. The approximately threefold rise in AMPK activity therefore also appears to be insufficient to elicit a detectable change in the expression level of GLUT4 in the basal state.

Normally, in the basal state, GLUT4 is excluded from the plasma membrane and resides in the endosomal system and specialised intracellular vesicles termed GLUT4 storage vesicles (Shepherd \& Kahn 1999, Welsh et al. 2005). The addition of insulin results in translocation of GLUT4 to the plasma membrane and 10- to 20-fold increases in GLUT4 levels at the plasma membrane (sarcolemma and T-tubule) are observed after insulin stimulation. Alterations in GLUT4 localisation that enhance glucose uptake are observed not only in response to insulin but also during exercise and muscle contraction, although the mechanisms and pathways are not fully defined (Jessen \& Goodyear 2005). AMPK has been implicated in the translocation of GLUT4 in response to exercise and contraction (Merrill et al. 1997, Hayashi et al. 1998, Mu et al. 2001,
Jessen \& Goodyear 2005, Sakamoto et al. 2005). Although we cannot completely eliminate an altered GLUT4 localisation, an initial evaluation of the GLUT4 molecules at the sarcolemma by electron microscopy (kindly performed by Dr John Lucocq and John James) gave no evidence for increased localisation of GLUT4 in this region in starved lean $\mathrm{C} 57 \mathrm{BL} / 6 \mathrm{G}_{\mathrm{M}}^{-1-}$ mice compared with $\mathrm{G}_{\mathrm{M}}^{+/+}$control mice. Furthermore, augmented expression and/or altered localisation of GLUT4 by AMPK are unlikely to underlie the differences between lean $\mathrm{C} 57 \mathrm{BL} / 6 \mathrm{G}_{\mathrm{M}}^{-1-}$ mice and obese $\mathrm{G}_{\mathrm{M}}^{-1-}$ mice because AMPK is activated in both lines, although to a slightly lower extent (approximately twofold) in obese $\mathrm{G}_{\mathrm{M}}^{-1-}$ mice compared with the approximately threefold in lean $\mathrm{C} 57 \mathrm{BL} / 6 \mathrm{G}_{\mathrm{M}}^{+/+}$mice.

Insulin stimulation of GLUT4 translocation to the membrane is believed to involve the phosphoinositide 3-kinase (PI3K) pathway (Shepherd \& Kahn 1999, Watson et al. 2004). The production of $\operatorname{PtdIns}(3,4,5) \mathrm{P} 3$ in the plasma membrane by PI3K leads to the activation of PKB in muscle cells (Ueki et al. 1998, Wang et al. 1999) and also stimulates atypical PKC isoforms (PKC $\lambda$ and PKCY) in adipocytes (Farese 2002). Both of these pathways have been implicated in GLUT4 translocation (Watson et al. 2004, Ishiki \& Klip 2005). However, PKB does not appear to be phosphorylated in the basal state in lean $\mathrm{G}_{\mathrm{M}}^{-1-}$ mice or control mice and in response to insulin it is similarly phosphorylated in $\mathrm{G}_{\mathrm{M}}^{-/-}$and control mice. Insulin levels are not significantly raised in lean $\mathrm{G}_{\mathrm{M}}^{-/-}$mice. Thus, there is no evidence for increased insulin signalling and alterations in the flux of the PI3K pathway in lean $\mathrm{C} 57 \mathrm{Bl} / 6 \mathrm{G}_{\mathrm{M}}^{-1-}$ mice compared with controls.

Interestingly, mice with a muscle-specific deletion of GLUT4 are glucose intolerant, insulin resistant and mildly diabetic (Zisman et al. 2000). Recent studies have shown that, rather surprisingly, glycogen levels are raised by $31-83 \%$ in different skeletal muscles of these mice in the fasted state, despite a $75 \%$ decrease in glucose transport (Kim et al. 2005). The underlying mechanism resides in part in a twofold increase in HKII, which leads to an increase in glucose-6-phosphate, an allosteric activator of GS. In addition, the levels of the glycogentargeting subunit $\mathrm{R}_{\mathrm{GL}} / \mathrm{G}_{\mathrm{M}}$ and the less abundant glycogen-targeting subunit $\mathrm{R} 5$ /protein targeting to glycogen (PTG) (Doherty et al. 1996, Printen et al. 1997) are increased 3.2- to 4·2-fold and PP1 activity is elevated. This increase in glycogen-targeted PP1 decreases phosphorylase activity and further enhances GS activity, leading to a rise in glycogen levels (Kim et al. 2005). However, in lean $\mathrm{C} 57 \mathrm{BL} / 6 \mathrm{G}_{\mathrm{M}}^{-1-}$ mice studied in this article, there was no change in the HK levels compared with $\mathrm{G}_{\mathrm{M}}^{+/+}$controls (Fig. 6) nor was the R5/PTG activity increased (Toole \& Cohen 2007).

Compensatory changes involving the upregulation of enzymes may often occur in mutant mice during 
embryonic development in successive generations. However, we found no evidence for augmented expression of AMPK, ACC, GLUT4, HKII, PKB and $\mathrm{R} 5 / \mathrm{PTG}$ in lean $\mathrm{C} 57 \mathrm{BL} / 6 \mathrm{G}_{\mathrm{M}}^{-1-}$ mice compared with $\mathrm{G}_{\mathrm{M}}^{+/+}$controls, although such alterations might be expected to ameliorate the phenotype of the lean $\mathrm{C} 57 \mathrm{BL} / 6 \mathrm{G}_{\mathrm{M}}^{-1-}$ mice. Overall, the elevation of AMPK $\alpha 2$ activity in lean C57BL/ $6 \mathrm{G}_{\mathrm{M}}^{-1-}$ mice is rather small and appears to be insufficient to appreciably alter the downstream targets of AMPK.

The differences between lean $\mathrm{C} 57 \mathrm{BL} / 6 \mathrm{G}_{\mathrm{M}}^{-1-}$ mice and obese $\mathrm{G}_{\mathrm{M}}^{-1-}$ mice do not appear to reside in the differences in AMPK activity, which are marginal. A more likely explanation, as discussed above, is the presence of one or more genes in the 129/Ola background interacting with the $\mathrm{G}_{\mathrm{M}}^{-1-}$ alleles. Although we cannot exclude an additional alteration closely linked to the $\mathrm{G}_{\mathrm{M}}$ gene, such a mutation would have to be very closely linked to the original $\mathrm{G}_{\mathrm{M}}$ disruption, but probably not in the adjacent genes since it was eliminated by six to ten backcrosses. In addition, the mutation would have to give rise to glucose intolerance, insulin resistance and obesity, since $\mathrm{G}_{\mathrm{M}}^{+/+}$ littermates of the obese $\mathrm{G}_{\mathrm{M}}^{-1-}$ mice did not develop the prediabetic phenotype. Genetic interaction of $\mathrm{G}_{\mathrm{M}}$ with a gene in the 129/Ola background would therefore appear more likely. Elevated triglycerides were observed in the blood plasma of 2-5 month obese $\mathrm{G}_{\mathrm{M}}^{-1-}$ mice suggesting that a plausible mechanism underlying the development of glucose intolerance in these mice is that the higher lipid levels may lead to obesity and substantially decrease the transport of glucose into the skeletal muscle. Decreased glucose transport may underlie the insulin resistance phenotype, but it should be noted that obesity and insulin resistance are not always linked (Uysal et al. 2000). The influence of the genetic background on the phenotype of gene knockout models has been noted in other instances. For example, depending on the genetic background, insulin receptor substrate 2 knockout mice may die due to a combination of impaired insulin action and insulin deficiency on a C57BL/6×129/Sv background (Withers et al. 1998) or develop diabetes with no insulin deficiency on a C57BL/6×CBA background (Kubota et al. 2000).

In vitro analyses predicted that phosphorylase, $\mathrm{PhK}$ and GS are substrates of PP1- $\mathrm{G}_{\mathrm{M}}$. Biochemical analyses of $\mathrm{G}_{\mathrm{M}}^{-/-}$ mice have shown that in the fasted state phosphorylase is hyperphosphorylated on Ser14 with increase of activity, while GS is hyperphosphorylated on Ser640 and Ser644 with decrease in activity compared with controls, confirming that these enzymes are in vivo substrates of PP1- $\mathrm{G}_{\mathrm{M}}$ (Table 2). From in vitro studies, it was observed that $\mathrm{PhK}$ is a better substrate for PP1 than it is for PP2A, PP2B/calcineurin or the $\mathrm{Mg} 2+-$ dependent protein phosphatases (PPM1/PP2C) (Ingebritsen \& Cohen 1983) and it can be inactivated by PP1-G $\mathrm{G}_{\mathrm{M}}$ in vitro (Hubbard \& Cohen 1989). In addition, both $\mathrm{PhK}$ and $\mathrm{PP} 1-\mathrm{G}_{\mathrm{M}}$ are bound to glycogen. The $\mathrm{pH} 6 \cdot 8 / \mathrm{pH} 8 \cdot 6$ activity ratios presented here indicate that $\mathrm{PhK}$ is hyperphosphorylated on its regulatory $\beta$-subunit in the basal state, demonstrating for the fist time that $\mathrm{PhK}$ is an in vivo substrate of $\mathrm{PP} 1-\mathrm{G}_{\mathrm{M}}$. The only other enzyme that we found to be hyperphosphorylated with alteration of activity was AMPK $\alpha 2$, but there is no in vitro data linking $\mathrm{PP}^{-\mathrm{G}_{\mathrm{M}}}$ with dephosphorylation of AMPK. The low level of activation and phosphorylation of AMPK $\alpha 2$ in $\mathrm{G}_{\mathrm{M}}^{-1-}$ mice also support the concept that this alteration is likely to arise as a secondary event, possibly as a consequence of lower cellular energy in the presence of low levels of glycogen.

\section{Acknowledgements}

This work was supported by Diabetes UK and the Medical Research Council, UK. J P and I R K are recipients of postgraduate studentships from the Medical Research Council, UK. We thank Dr Kei Sakamoto for helpful advice and Derek Black for technical assistance. The authors declare that there is no conflict of interest that would prejudice the impartiality of this scientific work.

\section{References}

Baldwin KM, Reitman JS, Terjung RL, Winder WW \& Holloszy JO 1973 Substrate depletion in different types of muscle and in liver during prolonged running. American Journal of Physiology 225 1045-1050.

Cohen P 1983 Phosphorylase kinase from rabbit skeletal muscle. Methods in Enzymology 99 243-250.

Cohen P 1999 The Croonian Lecture 1998. Identification of a protein kinase cascade of major importance in insulin signal transduction. Philosophical Transactions of the Royal Society of London. Series B354 485-495.

Cohen PTW \& Cohen P 1973 Skeletal muscle phosphorylase kinase deficiency. Detection of a protein lacking any activity in ICR/IAn mice. FEBS Letters 29 113-116.

DeFronzo RA 1997 Pathogenesis of type 2 diabetes: metabolic and molecular implications for identifying diabetes. Diabetes Reviews $\mathbf{5}$ 177-269.

Delibegovic M, Armstrong CA, Dobbie L, Watt PW, Smith AJH \& Cohen PTW 2003 Disruption of the striated muscle glycogen targeting subunit, PPP1R3A, of protein phosphatase 1 leads to increased weight gain, fat deposition and development of insulin resistance. Diabetes 52 596-604.

Doherty MJ, Young PR \& Cohen PTW 1996 Amino acid sequence of a novel protein phosphatase 1 binding protein (R5) which is related to the liver and muscle specific glycogen binding subunits of protein phosphatase 1. FEBS Letters 399 339-343.

Doney ASF, Fischer B, Cecil JE, Cohen PTW, Boyle DI, Leese G, Morris AD \& Pamer CNA 2003 Male predonderance in early diagnosed type 2 diabetes is associated with the ARE insertion/deletion polymorphism in the PPP1R3A locus. BMC Genetics 411.

Farese RV 2002 Function and dysfunction of aPKC isoforms for glucose transport in insulin-sensitive and insulin-resistant states. American Journal of Physiology. Endocrinology and Metabolism 283 E1-E11.

Hansen L \& Pedersen O 2005 Genetics of type 2 diabetes mellitus: status and perspectives. Diabetes, Obesity and Metabolism 7 122-135.

Hardie DG \& Sakamoto K 2006 AMPK: a key sensor of fuel and energy status in skeletal muscle. Physiology 21 48-60.

Hardie DG, Hawley SA \& Scott JW 2006 AMP-activated protin kinase development of the energy sensor concept. Journal of Physiology $\mathbf{5 7 4} 7-15$. 
Hayashi T, Hirschman MF, Kurth EJ, Winder WW \& Goodyear LJ 1998 Evidence for $5^{\prime}$ AMP-activated protein kinase mediation of the effect of muscle contraction on glucose transport. Diabetes 47 1369-1373.

Hubbard MJ \& Cohen P 1989 Regulation of protein phosphatase-1G from rabbit skeletal muscle. 2. Catalytic subunit translocation is a mechanism for reversible inhibition of activity toward glycogenbound substrates. European Journal of Biochemistry 186 711-716.

Imamura T, Huang J, Dalle S, Ugi S, Usui I, Luttrell LM, Miller WE, Lefkowitz RJ \& Olefsky JM $2001 \beta$-Arrestin-mediated recruitment of the Src family kinase Yes mediates endothelin-1-stimulated glucose transport. Journal of Biological Chemistry 276 43663-43667.

Ingebritsen TS \& Cohen P 1983 Protein phosphatases: properties and role in cellular regulation. Science 221 331-338.

Ishiki M \& Klip A 2005 Minireview: recent developments in the regulation of glucose transporter-4 traffic: new signals, locations and partners. Endocrinology 146 5071-5078.

James DE, Brown R, Navarro J \& Pilch PF 1988 Insulin-regulatable tissues express a unique insulin-sensitive glucose transport protein. Nature 333 183-185.

Jessen N \& Goodyear LJ 2005 Contraction signalling to glucose transport in skeletal muscle. Journal of Applied Physiology 99 330-337.

Kahn BB, Alquier T, Carling D \& Hardie DG 2005 AMP-activated protein kinase: ancient energy guage provides clues to modern understanding of metabolism. Cell Metabolism 1 15-25.

Kilimann MW, Zander NF, Kuhn CC, Crabb JW, Meyer HE \& Heilmeyer LM, Jr. 1988 The $\alpha$ and $\beta$ subunits of phosphorylase kinase are homologous: cDNA cloning and primary structure of the beta subunit. PNAS 85 9381-9385.

Kim Y-B, Peroni OD, Aschenbach WG, Minokoshi Y, Kotani K, Zisman A, Kahn CR, Goodyear LJ \& Kahn BB 2005 Musclespecific deletion of the Glut4 glucose transporter alters multiple regulatory steps in glycogen metabolism. Molecular and Cellular Biology 25 9713-9723.

Krebs EG 1972 In Current Topics in Cellular Regulation, vol 5, pp 99-133. Eds BL Horecker \& ER Stadtman. New York: Academic Press.

Kubota N, Tobe K, Terauchi Y, Eto K, Yamauchi T, Suzuki R, Tsubamoto Y, Komeda K, Nakano R, Miki H et al. 2000 Disruption of insulin receptor substrate 2 causes type 2 diabetes because of liver insulin resistance and lack of compensatory beta-cell hyperplasia. Diabetes 49 1880-1889.

Merrill GF, Kurth EJ, Hardie DG \& Winder WW 1997 AICA riboside increases AMP-activated protein kinase, fatty acid oxidation and glucose uptake in rat muscle. American Journal of Physiology 273 E1107-E1112.

Mu J, Brozinick JT, Jr, Valladares O, Bucan M \& Birnbaum MJ 2001 A role for AMP-activated protein kinase in contraction-and hypoxia-regulated glucose transport in skeletal muscle. Molecular Cell 7 1085-1094.

O'Rahilly S, Barroso I \& Wareham NJ 2005 Genetic factors in type 2 diabetes: the end of the beginning? Science 307 370-373.

Pederson BA, Schroeder JM, Parker GE, Smith MW, DePaoli-Roach AA \& Roach PJ $2005 a$ Glucose metabolism in mice lacking muscle glycogen synthase. Diabetes 54 3466-3473.

Pederson BA, Cope CR, Schroeder JM, Smith MW, Irimia JM, Thurberg BL, DePaoli-Roach AA \& Roach PJ $2005 b$ Exercise capacity of mice genetically lacking muscle glycogen synthase: in mice, muscle glycogen is not essential for exercise. Journal of Biological Chemistry 280 17260-17265.

Printen JA, Brady MJ \& Saltiel AR 1997 PTG, a protein phosphatase 1-binding protein with a role in glycogen metabolism. Science $\mathbf{2 7 5}$ $1475-1478$.

Roe JH \& Dailey RE 1966 Determination of glycogen with the anthrone reagent. Analytical Biochemistry 15 245-250.

Saha AK \& Ruderman NB 2003 Malonyl-CoA and AMP-activated protein kinase: an expanding partnership. Molecular and Cellular Biochemistry 253 65-70.
Sakamoto K, McCarthy A, Smith D, Green KA, Hardie DG, Ashworth A \& Alessi DR 2005 Deficiency of LKB1 in skeletal muscle prevents AMPK activation and glucose uptake during contraction. EMBO Journal 24 1810-1820.

Savage DB, Agostini M, Barroso I, Gurnell M, Luan JA, Meirhaeghe A, Harding A, Ihrke G, Ratanayagam O, Soos M et al. 2002 Digenic inheritance of severe insulin resistance in a human pedigree. Nature Genetics 31 379-384.

Shepherd PR \& Kahn BB 1999 Glucose transporters and insulin action. New England Journal of Medicine 341 248-257.

Shulman GI 2000 Cellular mechanisms of insulin resistance. Journal of Clinical Investigation 106 171-176.

Simpson EM, Linder CC, Sargent EE, Davisson MT, Mobraaten LE \& Sharp JJ 1997 Genetic variation among 129 substrains and its importance for targeted mutagenesis in mice. Nature Genetics 16 19-27.

Stewart A, Hemmings BA, Cohen P, Goris J \& Merlevede W 1981 The ATP-Mg dependent protein phosphatase and protein phosphatase-1 have identical substrate specificities. European Journal of Biochemistry 115 197-205.

Suzuki Y, Lanner C, Kim J-H, Vilardo PG, Zhang H, Yang J, Cooper LD, Steele M, Kennedy A, Bock CB et al. 2001 Insulin control of glycogen metabolism in knockout mice lacking the muscle-specific protein phosphatase PP1G/RGL. Molecular and Cellular Biology 21 2683-2694.

Toole BJ \& Cohen PTW 2007 The skeletal muscle-specific glycogen-targeted protein phosphatase 1 plays a major role in the regulation of glycogen metabolism by adrenaline in vivo. Cellular Signalling 19 1044-1055.

Ueki K, Yamamoto-Honda R, Kaburagi Y, Yamauchi T, Tobe K, Burgering BM, Coffer PJ, Komuro I, Akanuma Y, Yazaki Y et al. 1998 Potential role of protein kinase B in insulin-induced glucose transport, glycogen synthesis, and protein synthesis. Journal of Biological Chemistry 273 5315-5322.

Uysal KT, Scheja L, Wiesbrock SM, Bonner-Weir S \& Hotamisligil GS 2000 Improved glucose and lipid metabolism in genetically obese mice lacking aP2. Endocrinology 141 3388-3396.

Wang Q, Somwar R, Bilan PJ, Liu Z, Jin J, Woodgett JR \& Klip A 1999 Protein kinase B/Akt participates in GLUT4 translocation by insulin in L6 myoblasts. Molecular and Cellular Biology 19 4008-4018.

Watson RT, Kanzaki M \& Pessin JE 2004 Regulated membrane trafficking of the insulin responsive glucose transporter 4 in adipocytes. Endocrine Reviews 25 177-204.

Welsh GI, Hers I, Berwick DC, Dell G, Wherlock M, Birkin R, Leney S \& Tavaré JM 2005 Role of protein kinase B in insulin-regulated glucose uptake. Biochemical Society Transactions 33 346-349.

Withers DJ, Gutierrez JS, Towery H, Burks DJ, Ren JM, Previs S, Zhang Y, Bernal D, Pons S, Shulman GI et al. 1998 Disruption of IRS-2 causes type 2 diabetes in mice. Nature 391 900-904.

Xia J, Scherer SW, Cohen PTW, Majer M, Xi T, Norman RA, Knowler WC, Bogardus C \& Prochazka M 1998 A common variant in PPP1R3 associated with insulin resistance and type-2 diabetes. Diabetes 47 1519-1524.

Zisman A, Peroni OD, Abel ED, Michael MD, Mauvais-Jarvis F, Lowell BB, Wojtaszewski JFP, Hirshman MF, Virkamaki A, Goodyear LJ et al. 2000 Targeted disruption of the glucose transporter 4 selectively in muscle causes insulin resistance and glucose intolerance. Nature Medicine 6 924-928.

Zorzano A, Palacin M \& Guma A 2005 Mechanisms regulating GLUT4 glucose transporter expression and glucose transport in skeletal muscle. Acta Physiologica Scandinavica 183 43-58.

Received in final form 7 November 2007

Accepted 19 November 2007

Made available online as an Accepted Preprint 19 November 2007 